\title{
EKTOPARASIT PADA IKAN BUDIDAYA DI PERAIRAN TELUK AMBON
}

\author{
Inem Ode \\ Staf Pengajar FPIK UNIDAR-Ambon, e-mail: -
}

\begin{abstract}
ABSTRAK
Penelitian ini bertujuan untuk mengetahui jenis-jenis ektoparasit apa saja yang menginfeksi ikan budidaya di Perairan Teluk Ambon dan seberapa besar tingkat serangannya. Dengan menggunakan menggunakan metode observasi di lapangan dan pengamatan di laboratorium. Sampel ikan sebanyak 60 ekor diambil dari 3 Keramba jaring apung (KJA) yang berbeda, KJA pertama di perairan desa Waiheru, KJA kedua di perairan sekitar Tanjung Martafons Desa Poka, dan KJA ketiga di perairan desa Galala. Pemeriksaan parasit dilakukan di Laboratorium Hama dan Penyakit Ikan, Stasiun Karantina Ikan Kelas I Ambon dan Laboratorium Hama dan Penyakit Ikan BBL Ambon. Identifikasi parasit dilakukan berpedoman pada Kabata (1985) dan Grabda (1991). Hasil pengamatan diperoleh 90 individu ektoparasit yang menginfeksi ikan kerapu macan (Epinephelus fuscogutattus) dan 61 individu ektoparasit yang menginfeksi ikan Kuwe (Caranx ignobilis). Hasil identifikasi diketahui jenis parasit yang menyerang ikan budidaya di perairan Teluk Ambon, antara lain Benedenia, Haliotrema, Diplectanum dan Microcotyle sp. Parasit Microcotyle sp yang ditemukan pada KJA di desa Poka memiliki tingkat prevalensi tertinggi $85 \%$, sedangkan parasit dengan intensitas tertinggi 16,6 ind/ekor ditemukan pada jenis Haliotrema sp dari KJA di perairan desa Waiheru. Tingkat serangan ektoparasit tertinggi pada organ Insang.
\end{abstract}

Kata Kunci: Ektoparasit, Ikan budidaya, Perairan Teluk Ambon

\section{PENDAHULUAN}

\subsection{Latar Belakang}

Kunci pokok di dalam peningkatan produksi budidaya perikanan adalah kesehatan ikan yang dipelihara. Semakin luas dan semakin intensif usaha budidaya ikan maka semakin meningkat intensitas serangan penyakit. Dalam budidaya ikan, penyakit ikan dapat mengakibatkan kerugian ekonomis. Karena penyakit dapat menyebabkan kekerdilan, periode pemeliharaan lebih lama, tingginya konversi pakan, tingkat padat tebar yang rendah dan kematian, sehingga dapat mengakibatkan menurunnya atau menghilangnya produksi. Penyakit ikan dapat didefenisikan sebagai segala sesuatu yang dapat menimbulkan gangguan suatu fungsi atau struktur dari alat tubuh atau sebagian alat tubuh, baik secara langsung maupun tidak langsung (Kordi, 2004).

Perkembangan usaha budidaya ikan di hatcheri dan sentra budidaya pembesaran ternyata diikuti pula oleh berjangkitnya berbagai jenis penyakit, yaitu penyakit infeksi virus jenis viral nervous necrosis/VNN (Zafran et al., 2002 ; Zafran dan Yuasa, 1999), penyakit infeksi bakteri dari genus Vibrio dan Flexibacter, penyakit infeksi parasit Hirudinea (Roza \& Johnny, 2006; protozoa Scuticociliata (Zafran et al., 2005), parasit Amyloodinium ocellatum, Cryptocarion irritans, Neobedenia (Johnny et al., 2007), dan endoparasit Ichthyodinium chabelardi (Zafran \& Hutapea, 2008).

Salah satu sumber penyakit yang sering menyerang ikan budidaya adalah penyakit yang disebabkan oleh aktifitas organisme 

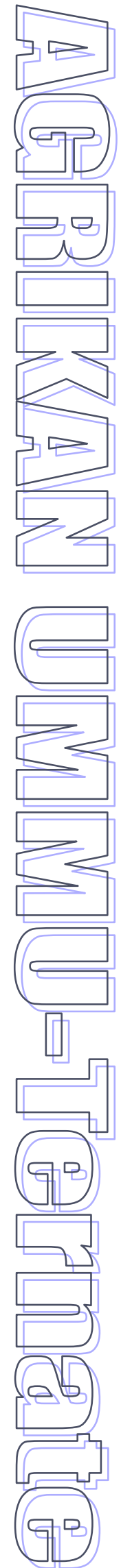

parasit. Parasit adalah organisme yang memanfaatkan organisme lain yang berbeda jenis untuk tempat berlindung dan mendapatkan makanan. Menurut Irianto (2005), serangan parasit merupakan hasil interaksi yang tidak serasi antara faktor lingkungan, kondisi ikan, dan organisme parasit. Interaksi yang tidak serasi ini menyebabkan stres pada ikan sehingga mekanisme pertahanan diri yang dimilikinya menjadi lemah dan akhirnya mudah diserang oleh organisme parasit. Roza dan Johnny (2006), menyatakan bahwa parasit yang menyerang ikan terdiri dari ektoparasit yaitu parasit yang menginfeksi organ luar ikan (kepala, kulit, dan insang), dan endoparasit yaitu parasit yang menginfeksi organ dalam. Selain itu parasit dapat bersifat spesifik yaitu menyerang jenis-jenis ikan tertentu atau menyerang ikan pada umur dan ukuran tertentu.

Wahyuni (1991) dalam Ode (2001), menyatakan bahwa parasit merupakan salah satu faktor penghambat pada usaha budidaya ikan. Parasit dapat menyebabkan kematian dalam jumlah banyak pada ikan budidaya terutama benih ikan. Beberapa parasit ikan seperti Lernaea sp, dan Myxobulus seringkali menyebabkan kerugian sebesar $30-60 \%$ dari usaha produksi pembeihan. Dactylogyrus dapat menyebabkan kematian pada benih ikan mas sebesar 80 - 100\%. Lebih lanjut Zafran (2009) menyatakan bahwa penyakit ikan merupakan salah satu faktor pembatas yang sangat mempengaruhi jumlah dan mutu ikan budidaya. Mengingat efek parasit terhadap ikan (sebagai inang) berupa kerusakan mekanik, pengambilan nutrien serta efek toksik dan litik, dapat menurunkan kepadatan stok ikan,dan menurunkan mutu ikan akibat cacat.

Budidaya ikan di Maluku masih terkonsentrasi pada lokasi-lokasi tertentu, namun kemungkinan penyebaran penyakit dari dan ke lokasi-lokasi tersebut perlu dipantau secara berkala (Littik dan Kamaruddin, 2006). Selanjutnya menurut Zafran, (2009), Pemantauan atau monitoring penyakit harus rutin dilakukan karena penyakit itu akan selalu berkembang sesuai dengan perkembangan budidaya ikan.
Tingkat serangan suatu jenis parasit dapat ditentukan dengan nilai prevalensi dan Intensitas. Dalimunthe (2006) mengemukakan bahwa tingkat penyerangan suatu parasit ditetukan dengan prevalensi, sedangkan tingkat keganasan suatu parasit ditentukan dengan intensitas.

\subsection{Tujuan dan Manfaat Penelitian}

Penelitian ini bertujuan untuk mengetahui jenis-jenis ektoparasit apa saja yang menginfeksi ikan budidaya di perairan Teluk Ambon dan seberapa besar tingkat serangannya. Penelitian ini diharapkan dapat bermanfaat bagi pengembangan ilmu pengetahuan dan diperlukan untuk pemetaan penyebaran parasit tersebut serta upaya pengendaliannya.

\section{Metode Penelitian}

Penelitian ini dilakukan pada bulan Juni 2014. Metode yang digunakan dalam penelitian ini adalah metode observasi di lapangan dan pengamatan di laboratorim.

Pengukuran panjang dengan penggaris berskala dan ditimbang beratnya dengan triapelbeam Ohause. Pemeriksaan ektoparasit pada organ tubuh ikan yang meliputi lendir/kulit, insang, sirip dan mata. Lendir diambil dengan cara dikerik dengan spatula mulai dari kepala hingga ke bagian ekor, Sampel ikan diambil pada 3 Keramba jaring apung (KJA) yang berbeda, KJA pertama di perairan desa Waiheru, KJA kedua di perairan sekitar tanjung martafons Desa Poka, dan KJA ketiga di perairan desa Galala.

Sampel ikan diambil sebanyak 20 ekor disetiap lokasi penelitian. Pemeriksaan parasit dilakukan di Laboratorium Hama dan Penyakit Ikan, Stasiun Karantina Ikan Kelas I Ambon dan Laboratorium Hama dan Penyakit Ikan BBL Ambon. Sebelum memulai pemeriksaan parasit, ikan diukur pengambilan organ dengan cara dipotong dengan gunting dan ditempatkan pada gelas objek dan selanjutnya diamati di bawah mikroskop. Identifikasi parasit dilakukan berpedoman pada Kabata (1985), dan Grabda (1991).

Untuk mengalisis tingkat serangan ektoparasit dilakukan perhitungan prevalensi dan intensitas menurut Zafran, (2009). 
Prevalensi $(\mathrm{P})=\mathrm{N} / \mathrm{n} \times 100 \%$.

Dimana :

$\mathbf{P}=$ Prevalensi $(\%)$

$\mathrm{N}$ = Jumlah sampel yang terinfeksi (ekor)

n = Jumlah sampel yang diamati (ekor)

$$
\text { Intensitas (I) }=\mathbf{P} / \mathrm{N}
$$

Dimana :

$\mathrm{I}=$ Intensitas serangan parasit ( ind/ekor)

$\mathbf{P}=$ Jumlah parasit yang menginfeksi (ind)

$\mathrm{N}=$ Jumlah sampel yang terinfeksi (ekor)

\section{HASIL DAN PEMBAHASAN}

\subsection{Kehadiran Ektoparasit}

Berdasarkan hasil pengamatan terhadap 20 ekor ikan kerapu macan Epinephelus fuscogutattus dan 40 ekor ikan Kuwe Caranx ignobilis yang dipelihara pada pada tiga keramba jaring apung, diperoleh 90 individu ektoparasit yang menginfeksi ikan kerapu macan Epinephelus fuscogutattus dan 61 individu ektoparasit yang menginfeksi ikan Kuwe Caranx ignobilis.

Keramba jaring apung di Perairan Desa Waiheru, berat sampel ikan kerapu macan Epinephelus fuscogutattus berkisar antara 110 325 gram, panjang totalnya berkisar antara 17$29 \mathrm{~cm}$. Dari 20 ekor ikan yang diperiksa, 14 ekor yang terinfeksi ektoparasit sedangkan 6 ekor bebas ektoparasit. Ektoparasit yang menginfeksi 14 ekor ikan sebanyak 90 individu.

Keramba jaring apung di Perairan Desa Poka, berat ikan Kuwe Caranx ignobilis berkisar antara 38,4-84,1 gram dengan panjang total $13-18 \mathrm{~cm}$. Dari 20 ekor ikan yang diperiksa, 17 ekor terinfeksi ektoparasit sedangkan 3 ekor bebas ektoparasit. Ektoparasit yang menginfeksi 17 ekor ikan sebanyak 37 individu.

Keramba jaring apung di desa Galala, berat ikan Kuwe Caranx ignobilis berkisar antara 35 - 220 gram dengan panjang total 14 $24 \mathrm{~cm}$. Dari 20 ekor ikan yang diperiksa, 14 ekor terinfeksi ektoparasit sedangkan 6 ekor bebas ektoparasit. Ektoparasit yang menginfeksi 14 ekor ikan sebanyak 24 individu.

Tabel 1 terlihat bahwa jumlah ektoparasit yang ditemukan berbeda untuk tiap jenis ikan, pada ikan kerapu ditemukan jenis dan jumlah ektoparasit yang lebih banyak dibandingkan pada jenis ikan kuwe, hal ini menurut Yuniar (1999), bahwa parasit dapat bersifat spesifik yaitu menyerang jenis-jenis ikan tertentu atau menyerang ikan pada umur dan ukuran tertentu. Selain itu perbedaan jenis dan jumlah ektoparasit juga diduga disebabkan oleh kondisi lingkungan dan juga daya tahan tubuh dari inang. Ode (2001), mengemukakan bahwa kemampuan ikan untuk mempertahankan diri dari serangan penyakit sangat bergantung pada kesehatan ikan dan kondisi lingkungan.

Ikan sehat mempunyai kemampuan untuk mempertahankan diri dari serangan berbagai penyakit karena memiliki sistem pertahanan diri atau kekebalan tubuh. Kondisi ingkungan yang jelek, menyebabkan stres pada ikan sehingga mekanisme pertahanan diri yang dimilikinya menjadi menurun sehingga ikan mudah terserang penyakit.

Tabel 1. Jumlah Sampel Ikan yang Diamati dan Jumlah Ektoparasit yang Ditemukan

\begin{tabular}{llcc}
\hline \multicolumn{1}{c}{ Lokasi Pengambilan Sampel } & \multicolumn{1}{c}{ Jenis Ikan } & $\begin{array}{c}\text { Jumlah Sampel } \\
\text { Ikan (ekor) }\end{array}$ & $\begin{array}{c}\text { Jumlah Ektoparasit yang } \\
\text { ditemukan (Individu) }\end{array}$ \\
\hline KJA di Perairan Desa Waiheru & Kerapu macan & 20 & 90 \\
KJA di Perairan Desa Poka & Kuwe & 20 & 37 \\
KJA di Perairan Desa Galala & Kuwe & 20 & 24 \\
\hline \multicolumn{1}{c}{ Total } & & 60 & 151 \\
\hline
\end{tabular}

\subsection{Identifikasi Jenis Ektoparasit dan Spesifikasinya}

Hasil identifikasi diketahui jenis parasit yang menyerang ikan budidaya di perairan Teluk Ambon, antara lain Benedenia, Haliotrema, Diplectanum dan Microcotyle sp. Benedenia adalah parasit yang dikenal juga dengan nama cacing kulit karena biasanya menempel pada bagian kulit ikan dan bisa menimbulkan iritasi kulit sebagai titik masuk infeksi sekunder. Grabda (1991) klasifikasikan Benedenia sp. adalah sebagai berikut Filum Platyhelminthes, Kelas Thrematoda monogenia, Ordo Dactylogyridae, Famili Capsylidae, Genus Benedenia. Morfologi Benidenia sp yaitu berbentuk oval (lonjong) dan gepeng dengan 

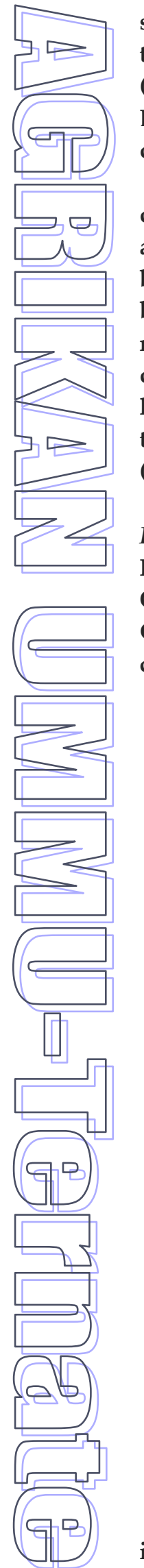

Parasit Diplectanum disebut juga cacing insang, merupakan parasit yang cukup berbahaya dan sering ditemukan pada ikan laut. Beberapa jenis parasit insang dapat menyebabkan kematian yang cukup serius berbahaya dan sering ditemukan pada ikan laut. Ikan kerapu yang terinfeksi memperlihatkan gejala klinis; menurunnya nafsu makan, tingkah laku berenang yang abnormal pada permukaan air, warna tubuh berubah menjadi pucat. Serangan berat dari parasit ini dapat merusak filamen insang dan kadang-kadang dapat menimbulkan kematian karena adanya gangguan pernapasan. Warna insang ikan kerapu yang terinfeksi terlihat pucat. Haliotrema yang ditemukan saat penelitian dapat dilihat pada Gambar 2.

Grabda (1991) Diplectanum sp
diklasifikasikan ke dalam Filum Platyhelminthes, Class Trematoda monogenea, Ordo Dactilogyridae, Famili Diplectanidae, Genus Diplectanum. Diplectanum sp yang ditemukan saat penelitian dapat dilihat pada Gambar 3.

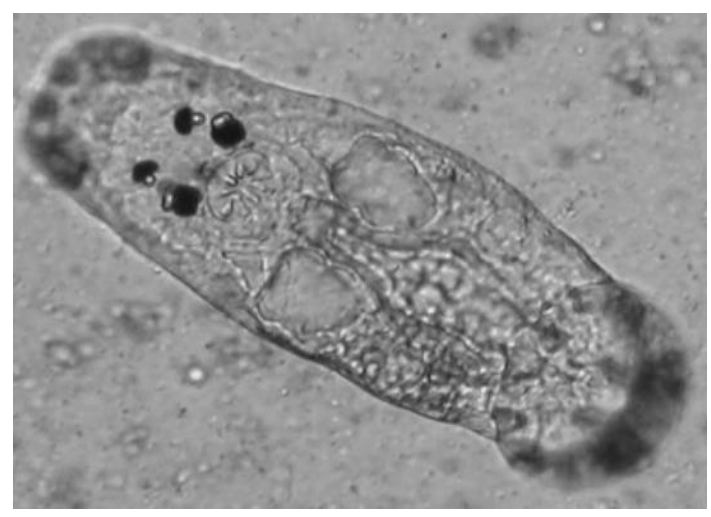

Gambar 2. Haliotrema sp

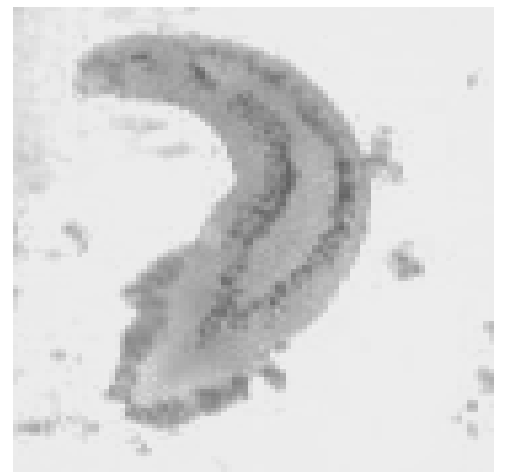

Gambar 6. Microcotyle sp

pada ikan yang dibudidaya parasit Diplectanum mempunyai kekhasan yang membedakannya dari spesies lain dalam Ordo Dactylogyridea yaitu mempunyai squamodisc (satu di ventral dan satu di dorsal), 


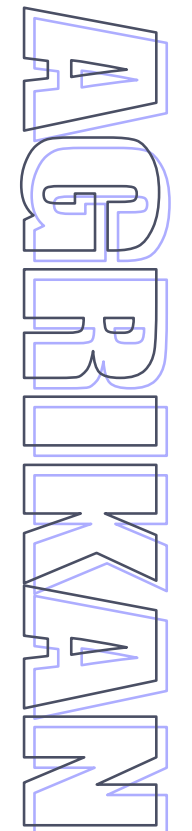

dan sepasang jangkar yang terletak berjauhan (Zafran, 2009). Parasit Diplectanum adalah parasit yang hidup pada insang ikan. Ikan kerapu yang terinfeksi Diplectanum terlihat bernapas lebih cepat dengan tutup insang yang selalu terbuka. Infeksi Diplectanum mempunyai hubungan erat dengan penyakit sistemik seperti vibriosis. Insang yang terinfeksi biasanya berwarna pucat dan produksi lendirnya berlebihan (Yuniar, 1999).

Microcotyle sp merupakan parasit dari kelas Monogenea, jenis parasit ini dikenal sebagai pemakan darah dan insang merupakan habitat mikro yang dapat menyediakan

dalam jumlah besar pada insang dapat mengakibatkan kerusakan jaringan yang menimbulkan anemia yang termasuk merupakan gejala umum parasitisme (Noble dan Noble, 1989). Microcotyle sp yang ditemukan selama penelitian dapat dilihat pada Gambar 4.

\subsection{Tingkat Serangan Ektoparasit}

Gangguan awal parasit terhadap ikan ditandai dengan adanya proses infeksi. Parasit yang menginfeksi ikan berfariasi tergantung pada keadaan fisik dan fisiologi yang terbuka serta kelimpahan parasit yang ditemukan.

Tabel 3. Jenis Ektoparasit, Prevalensi dan Intensitasnya

\begin{tabular}{ccccc}
\hline Jenis Parasit & $\begin{array}{c}\text { Ikan Terinfeksi } \\
\text { (Ekor) }\end{array}$ & $\begin{array}{c}\text { Parasit } \\
\text { (ind) }\end{array}$ & $\begin{array}{c}\text { Prevalensi } \\
\text { (\%) }\end{array}$ & $\begin{array}{c}\text { Intensitas } \\
\text { (ind/ekor) }\end{array}$ \\
\hline $\begin{array}{c}\text { KJA di Perairan Desa Waiheru } \\
\text { - Benedenia sp }\end{array}$ & 1 & 1 & 5 & 1 \\
- Haliotrema sp & 2 & 33 & 10 & 16,5 \\
- Diplectanum sp & 11 & 56 & 55 & 5,09 \\
$\begin{array}{l}\text { KJA di Perairan Desa Poka } \\
\text { - Microcotyle sp }\end{array}$ & 17 & 37 & 85 & 2,1 \\
$\begin{array}{l}\text { KJA di Perairan Desa Galala } \\
\text { - Microcotyle sp }\end{array}$ & 14 & 24 & 70 & 1,7 \\
\hline
\end{tabular}

Parasit Microcotyle sp yang ditemukan pada KJA di desa Poka memiliki tingkat prevalensi tertinggi $85 \%$, sedangkan parasit dengan intensitas tertinggi 16,6 ind/ekor ditemukan pada jenis Haliotrema sp dari KJA di perairan desa Waiheru. Menurut Indriyani (1998) bahwa intensitas 2-5 ind/ekor pada tubuh inang belum berbahaya dan bila intensitas 10 ind/ekor ke atas sudah membahayakan inang. Beberapa faktor yang mempengaruhi prevalensi dan intensitas parasit pada inang adalah faktor intrinsik seperti umur, ukuran ikan, kebiasaan makan dan tingkah laku ikan, serta faktor ekstrinsik seperti makanan ikan, perubahan musim, suhu air (Yuniar, 1999).

Ektoparasit yang temukan selama penelitian memiliki jenis dan jumlah yang berbeda, namun penyebarannya hanya terkonsentrasi pada organ insang. Perbedaan jenis dan jumlah parasit serta penyebarannya yang tidak merata pada bagian tubuh ikan menunjukan bahwa selama masa pemeliharaan ikan, telah terjadi kompetisi antar sesama parasit untuk mempertahankan jenisnya dan berusaha mempertahankan habitat mikro yang sesuai untuk mempertahankan kelangsungan hidup (Soumokil $d k k$., 2006).

Pada Tabel 4, insang merupakan organ yang paling banyak terinfeksi ektoparasit, hal ini dimungkinkan karena insang merupakan organ luar yang tertutup yang berhubungan dengan dunia luar, sehingga memungkinkannya terinfeksi parasit yang mencari tempat untuk berlindung dan memenuhi kebutuhan metabolismenya. Selain itu insang juga sebagai organ pernafasan yang dilewati darah dan oksigen melalui pembuluh kapiler.

Tabel 5, memperlihatkan tingkat serangan ektoparasit tertinggi pada organ Insang, ektoparasit Microcotyle sp memiliki tingkat penyerangan tertinggi, namun tingkat keganasan ektoparasit tertinggi terdapat pada jenis Haliotrema. Menurut Noble dan Noble (1989), di dalam jaringan atau ruang, parasit berusaha memilih lokasi yang sebaik mungkin untuk memperoleh kebebasan untuk makan dan bereproduksi secara maksimum dalam batasan yang ditentukan metabolisme parasit dan respon fisiologis inangnya. 
Tabel 4. Jenis, Jumlah dan Penyebaran Ektoparasit

\begin{tabular}{|c|c|c|c|c|c|}
\hline \multirow[b]{2}{*}{ Ektoparasit } & \multicolumn{4}{|c|}{ Bagian Tubuh Yang diamati } & \multirow{2}{*}{ Jumlah } \\
\hline & Kulit & Insang & Mata & Sirip & \\
\hline $\begin{array}{l}\text { KJA di Perairan Desa Waiheru } \\
\text { - Benedenia sp } \\
\text { - Haliotrema sp } \\
\text { - Diplectanum sp }\end{array}$ & $\begin{array}{l}1 \\
- \\
-\end{array}$ & $\begin{array}{l}- \\
33 \\
56\end{array}$ & $\begin{array}{l}- \\
-\end{array}$ & $\begin{array}{l}- \\
-\end{array}$ & \\
\hline Total & 1 & 89 & & & 90 \\
\hline $\begin{array}{l}\text { KJA di Perairan Desa Poka } \\
\text { - Microcotyle sp }\end{array}$ & - & 37 & - & - & \\
\hline Total & & 37 & & & 37 \\
\hline $\begin{array}{l}\text { KJA di Perairan Desa Galala } \\
\text { - Microcotyle sp } \\
\end{array}$ & - & 34 & - & - & \\
\hline Total & & 34 & & & 34 \\
\hline
\end{tabular}

Tabel 5. Jenis Ektoparasit, Prevalensi dan Intensitasnya pada Organ Tubuh Ikan

\begin{tabular}{lllcccc}
\hline No & $\begin{array}{c}\text { Bagian } \\
\text { Tubuh yang } \\
\text { Terinfeksi }\end{array}$ & $\begin{array}{c}\text { Jenis } \\
\text { Ektoparasit }\end{array}$ & $\begin{array}{c}\text { Jlh Parasit } \\
\text { (ind) }\end{array}$ & $\begin{array}{c}\text { Jlh Ikan } \\
\text { Terinfeksi } \\
\text { (ekor) }\end{array}$ & $\begin{array}{c}\text { Prevalensi } \\
\text { (\%) }\end{array}$ & $\begin{array}{c}\text { Intensitas } \\
\text { (ind/ekor) }\end{array}$ \\
\hline 1. & Insang & Haliotrema sp & 33 & 2 & 3,33 & 16,5 \\
& & Diplectanum sp & 56 & 11 & 18,3 & 5,09 \\
& & Microcotyle sp & 71 & 31 & 51,6 & 2,29 \\
2. & Kulit & Benedenia sp & 1 & 1 & 1,66 & 1 \\
\hline
\end{tabular}

\section{PENUTUP}

\subsection{Kesimpulan}

- Terdapat 90 individu ektoparasit yang menginfeksi ikan kerapu macan Epinephelus fuscogutattus dan 61 individu ektoparasit yang menginfeksi ikan Kuwe Caranx ignobilis.

- Ektoparasit yang menginfeksi ikan budidaya di perairan teluk Ambon terdiri dari Benedenia sp, Haliotrema sp, Diplectanum sp dan Microcotyle sp.

- Parasit Microcotyle sp yang ditemukan pada KJA di desa Poka memiliki tingkat prevalensi tertinggi $85 \%$, sedangkan parasit dengan intensitas tertinggi $16,6 \mathrm{ind} /$ ekor ditemukan pada jenis Haliotrema sp dari KJA di perairan desa Waiheru.

- Insang merupakan organ dengan tingkat serangan ektoparasit tertinggi.

\subsection{Saran}

Selain ektoparasit, identifikasi endoparasit juga perlu dilakukan untuk mendapatkan data yang lebih lengkap tentang penyakit parasitik pada ikan-ikan budidaya di perairan teluk Ambon. Selain juga perlu dilakukan pemeriksaan terhadap jenis-jenis ikan yang berbeda untuk mengetahui preferensi dari masing-masing organisme parasit.

\section{DAFTAR PUSTAKA}

Dalimunthe, 2006. Manajemen Penyakit Ikan. Diktat Kuliah. Laboratorium Parasit dan Penyakit Ikan, Fakultas Perikanan, Universitas Brawijaya. Malang.

Grabda, J. 1991. Marine Fish Parasitology: An Outline. Polish Scientific Publication, Warszawa. 306 pp.

Indriyani, N. 1999. Studi Parasit Menginfeksi Berbagai Jenis Ikan Baronang Siganus spp yang Ditangkap Dari Alam. Agriplus ; Hal 24

Irianto, A., 2005. Patologi Ikan Teleostei. Gadjah Mada University Press. Yogyakarta.

Johnny, F., A. Priyono dan D. Roza. 2007. Infeksi parasit pada induk ikan cobia, Rachycentron canadum dan upaya pengendaliannya. Buku Pengembangan Teknologi Budidaya Perikanan (Eds.). Achmad, T., et al., Hal. 269-277 
Kabata, Z. 1985. Parasites and diseases of fish cultured in the tropics. Taylor \& Francis. London \& Philadelphia. 518 pp.

Kordi, M, G. 2004. Penanggulangan Hama dan Penyakit Ikan. Penerbit Rineka Cipta. Jakarta.

Littik, S.A.M., dan Kamaruddin. 2006. Parasit dan bakteri Ikan Budidaya di Provinsi Maluku. Prosiding Konferensi Akuakultur Indonesia 2006. Universitas Diponegoro Semarang

Noble, E., R dan G., A Noble, 1989. Parasitologi (Biologi Parasit Hewan) Gadjah Mada University Press.

Ode, I., 2001. Studi Endoparasit pada benih ikan mas (Cyprinus carpio) pada kolam Balai Benih Ikan Abeli sawah, Kabupaten Kendari. Skripsi Program Studi Budidaya Perairan. Universitas haluoleo Kendari.

Roza, D. dan F. Johnny. 2006. Infeksi parasit hirudenia pada induk ikan kerapu lumpur, Epinephelus bleckeri dan kerapu batik, Epinephelus polyphekadion serta upaya penanggulangannya. Prosiding Seminar Nasional Tahunan III Hasil Penelitian Perikanan dan Kelautan, Jogyakarta, 27 Juli 2006. Hal. 201-206.

Soumokil, A.W., Littik, S.A.M., Wenno, P.A, 2006. Pengaruh Kecepatan Debit Air Terhadap Kehadiran Parasit Pada Ikan Mas Cyprinus carpio.Prosiding Konferensi Akuakultur Indonesia.

Yuniar, T, 1999. Inventarisasi Parasit Pada Ikan Laut Dari Tempat Pelelangan Ikan Kronjo. Tangerang. Skripsi Institut Pertanian Bogor.

Zafran., 2009. Penyakit parasitik pada ikan budidaya di daerah Bali. Makalah di sampaikan pada Seminar Nasional Kelautan V. Pada 23 April 2009. Universitas Hang Tuah Surabaya.

Zafran dan K. Yuasa. 1999. Sejarah penyakit VNN di Indonesia. Lolitkanta Newsletter, 15:3-4.

Zafran, I. Koesharyani, and K. Yuasa. 2002. Diseases of seabass, Lates calcarifer, larvae from hatchery in Indonesia. In Diseases in Asian Aquaculture IV. Asian Fisheries Society, Manila, Philippines. p 279-284.

Zafran, W. Andriyanto, dan T. Sutarmat. 2005. Infeksi protozoa Scuticociliata pada benih kerapu macan (Epinephelus fuscoguttatus) dan upaya pengendaliannya. Dalam Prosiding Seminar Nasional dan Kongres Biologi XIII. UGM Yogyakarta. p 281-284.

Zafran dan J.H. Hutapea. 2008. Beberapa kendala dalam pembenihan ikan napoleon (Cheilinus undulatus) di hatchery. Prosiding Seminar Nasional Kelautan IV. Universitas Hang Tuah, Surabaya 24 April 2008: II 207-210. 